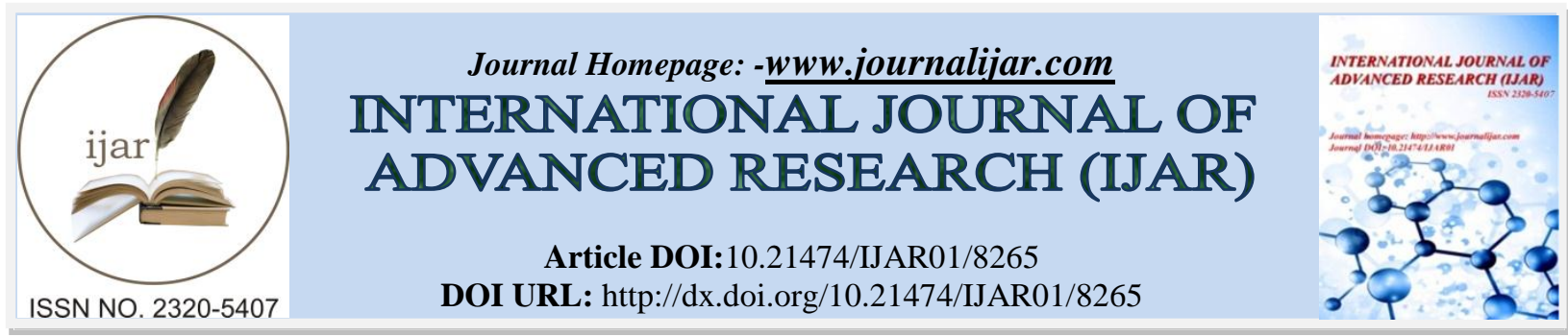

RESEARCH ARTICLE

\title{
PERFORMANCE EVALUATION OF MBR TECHNOLOGY WASTEWATER TREATMENT PLANT AT SOHAR PORT-A CASE STUDY.
}

\author{
Abdullah Mohammed Abdullah Al Ajmi ${ }^{1}$, Satyanarayana.S.V ${ }^{2}$ and Ramamohan Reddy Kasa ${ }^{3}$. \\ 1. Project Student, Caledonian College of Engineering, Muscat, Oman. \\ 2. Assistant Professor, National University of Science and Technology, Muscat, Oman. \\ 3. Professor, Center for Water Resources, Institute of Science \& Technology, JNTUH, Hyderabad, India.
}

\section{Manuscript Info}

\section{Manuscript History}

Received: 20 October 2018

Final Accepted: 22 November 2018

Published: December 2018

Keywords:-

COD, efficiency, effluent, influent, membrane bioreactor, treatment.

\begin{abstract}
The wastewater generated from the household is nearly $80 \%$ of their intake. Most of the wastewater treatment plants were using activated sludge process to treat sewage. The treatment efficiency of activated sludge process is less than $90 \%$. The latest technologies in the wastewater treatment are sequencing batch reactor and membrane bioreactor. The problem of membrane bioreactor technology is fouling. Due to fouling the flux of the filtration is decreasing. The aim of this project is to evaluate the treatment efficiency of MBR technology. The influent and effluent samples were collected from the Sohar Port were collected and analyzed as per the standard methods for the examination of water and wastewater. The treatment efficiency was calculated. The mean BOD removal efficiency was $97.6 \%$. The mean COD removal efficiency was $96.5 \%$.
\end{abstract}

Copy Right, IJAR, 2018,. All rights reserved.

\section{Introduction:-}

Study area:-

The Sohar is a port city of Sultanate of Oman. The GPS coordinates for Sohar are latitude $24.3461^{\circ} \mathrm{N}$ and longitude $56.7075^{\circ}$ E. The Sohar is a free economic zone with good number of industries. The population of Sohar is 2.2 million. The average consumption of water is 350 liters per day. The wastewater generated is nearly $80 \%$ of water consumption. The wastewater generated is $280 \mathrm{~L} /$ per capita/day. The total wastewater generated per day is $2.2 \times 10^{6}$ $\mathrm{x} 280=616,000 \mathrm{~m}^{3}$. The study area was shown in fig 1 .

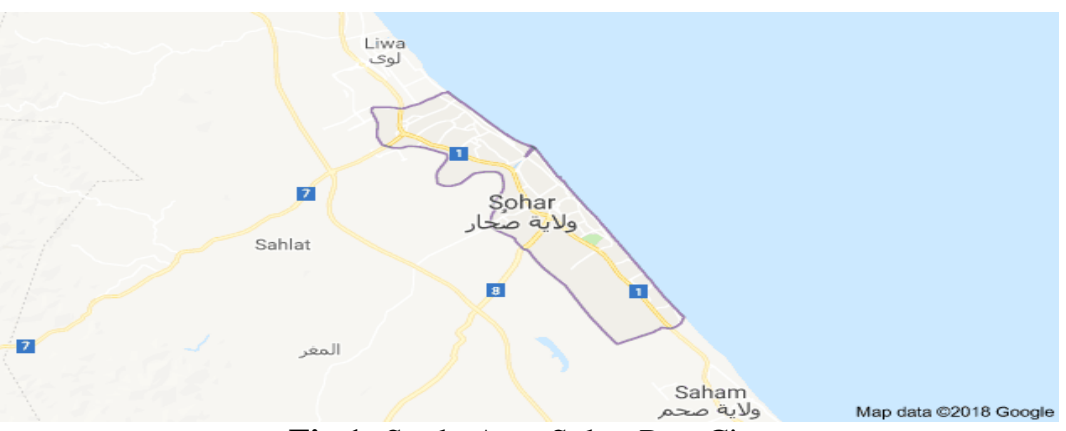

Fig 1:-Study Area Sohar Port City 
The conventional activated sludge process (CASP) treatment consists of primary, secondary and tertiary treatment. The primary treatment consists of screens, grit chamber and primary clarifier. Nearly 30 to $35 \%$ of BOD load reduced in the primary treatment. The secondary treatment consists of an anoxic tank, aeration tank and secondary clarifier. The efficiency of secondary treatment is nearly $60 \%$. The overall treatment efficiency of CASP is 90\%. Activated Sludge process has different problems like growth of filamentous bacteria and foaming. However it can be controlled by adding poly aluminum chloride coagulant (Pal.P 2014).The tertiary treatment deals with filtration and disinfection. The nature, composition and the biodegradability of organic matter plays an important role in the wastewater treatment (Ahansazan.B 2014). The conventional activated sludge process cannot be used for certain wastewaters. The leachate from landfill contains heavy metals and other dissolved organic matters. The MBR technology can be used to treat the leachate from the landfill (Ester Coppini).By using the MBR technology the treatment efficiency is increased by more than $96 \%$. The bottle neck of MBR technology is fouling (Oliver Terna Iorhemen, 2016). The increased suction on the membranes is causing fouling (Shim J, 2002). The CASP have many problems like removal of nitrogen, phosphorous and low sludge settleability (Andrade, 2013). The conventional wastewater treatment technologies which have like coagulation, sedimentation, aeration, clarification and chlorination have high operating cost (Jayashree 2012). The MBR technology revolutionized the wastewater treatment. (Naghizadeh.2011).

\section{Methodology:-}

The MBR process flow diagram is as shown in Fig 1.Six numbers of each influent and effluent samples were collected from the Sohar STP and analyzed for $\mathrm{pH}$, conductivity, COD, BOD, SS, DS and TS.

\section{Estimation of pH:-}

The $\mathrm{pH}$ meter calibrated by using $\mathrm{pH} 7.0$ and 9.2 buffer solutions. After calibration the influent and effluent samples were analyzed for $\mathrm{pH}$ values.

\section{Estimation of conductivity:-}

The conductivity values were estimated with conductivity meter with cell constant 1 . The values were expressed in $\mathrm{mS} / \mathrm{cm}$.

\section{Estimation of BOD:-}

The initial dissolved oxygen (D.O) values of influent and effluent samples were measured by using the Dissolved Oxygen meter. The samples were diluted and kept in an incubator at $20^{\circ} \mathrm{C}$ for five days. The D.O values were measured after 5 days.

BOD mg/l $=\left(\right.$ D. $0_{1}-$ D. $\left.0_{5}\right) \times$ Dilution Factor.

\section{Estimation of COD:-}

The COD is estimated with COD photometer by using COD veils of 0-1500 mg/l range.

Two milliliters of wastewater sample transferred quantitatively into the COD veil. One blank along with 6 samples were heated at $150^{\circ} \mathrm{C}$ for 2 hours. The COD veils were cooled to room temperature. The blank COD veil was inserted in the photometer and the photometer reading adjusted to zero. The samples were inserted into the photometer and milligrams COD values were noted.

\section{Calculation:-}

COD $\mathrm{mg} / \mathrm{l}=$ milligrams COD $\times 1000 /$ sample volume $(2 \mathrm{ml})$

Estimation of Suspended Solids:

The wastewater $100 \mathrm{ml}$ sample filtered through a Whatman No 40 filter paper. The filter paper was dried at $1050 \mathrm{C}$ and cooled in a desiccator.

\section{Calculation:-}

$\mathrm{SS} \mathrm{mg/l} \mathrm{=} \mathrm{[(residue} \mathrm{on} \mathrm{filter} \mathrm{paper})-($ tare mass of filter paper $)] \times 1000 /$ volume of sample $(100 \mathrm{ml})$. Estimation of Total Dissolved Solids

The wastewater $50 \mathrm{ml}$ sample is filtered through a Whatman No 42 filter paper. The 50 ml filtrate transferred quantitatively in to a previously dried and weighed evaporating dish. The dish was kept on a water bath. The filtrate was evaporated to dryness. 


\section{Calculation:-}

TDS mg/l = (Mass of dish plus residue grams- mass of dish grams $) \times 10^{6} /$ sample volume $(50 \mathrm{ml})$

Estimation of Total Solids

The unfiltered wastewater $50 \mathrm{ml}$ sample evaporated to dryness on a water bath.

\section{Calculation:-}

TS $\mathrm{mg} / \mathrm{l}=$ (Mass of dish plus residue grams- mass of dish grams) $\times 10^{6} /$ sample volume $(50 \mathrm{ml})$

TDS can also be calculated as given below.

TDS $=$ Total solids - Suspended solids.

\section{The Process:-}

The influent is passed through the screens to separate all suspended materials like paper, plastic. The influent is passed through equalization tank, anoxic tank and aeration tank. The aeration tank outlet is passed into the MBR compartment. The effluent is collected by creating suction in the MBR compartment. The effluent is disinfected by chlorination or zonation or UV sterilization.(Metcalf \& Eddy). The process flow diagram was shown in fig 2.

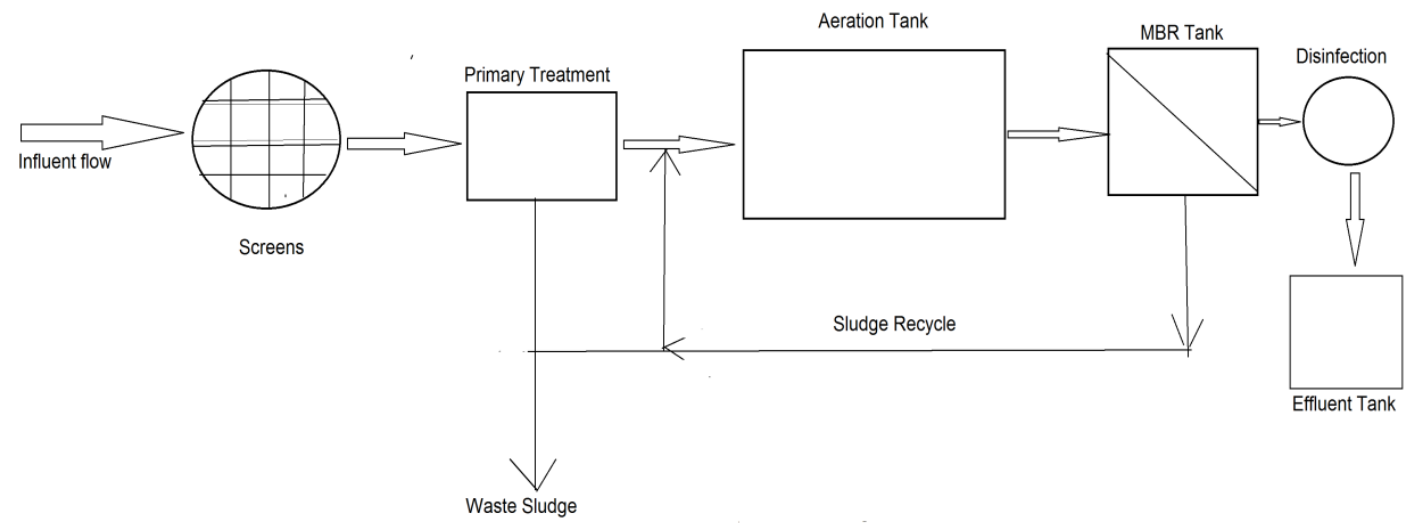

Fig 2 Process flow diagram of MBR technology

\section{Results:-}

The Influent samples analysis:-

The influent samples $\mathrm{pH}$ values varied from 6.89 to 7.1.The sample 2 has the lowest $\mathrm{pH} 6.89$ and the sample 4 has the highest $\mathrm{pH}$ 7.1.The conductivity values varied from $6.44 \mathrm{mS} / \mathrm{cm}$ to $8.4 \mathrm{mS} / \mathrm{cm}$. The sample 4 has the lowest value $6.44 \mathrm{mS} / \mathrm{cm}$ and the sample 1 has the highest value $8.4 \mathrm{mS} / \mathrm{cm}$. The BOD values varied from $250 \mathrm{mg} / \mathrm{l}$ to 340 $\mathrm{mg} / \mathrm{l}$. The sample 5 has the lowest BOD value $250 \mathrm{mg} / \mathrm{l}$ and the sample 2 has the highest BOD value $340 \mathrm{mg} / \mathrm{l}$. The COD values varied from $484 \mathrm{mg} / \mathrm{l}$ to $710 \mathrm{mg} / \mathrm{l}$. The sample 1 has the lowest COD value $484 \mathrm{mg} / \mathrm{l}$ and the sample 4 has the highest value $710 \mathrm{mg} / \mathrm{l}$. The suspended solids varied from $129 \mathrm{mg} / \mathrm{l}$ to $498 \mathrm{mg} / \mathrm{l}$. The sample 3 has the lowest value $129 \mathrm{mg} / \mathrm{l}$ and sample 1 has the highest value $498 \mathrm{mg} / \mathrm{l}$. The total dissolved solids values varied from $910 \mathrm{mg} / \mathrm{l}$ to $998 \mathrm{mg} / \mathrm{l}$. the sample 3 has the lowest value $910 \mathrm{mg} / \mathrm{l}$ and the sample 2 has the highest value $998 \mathrm{mg} / \mathrm{l}$. The total solids varied from $1039 \mathrm{mg} / \mathrm{l}$ to $1432 \mathrm{mg} / \mathrm{l}$. The sample 3 has the lowest value $1039 \mathrm{mg} / \mathrm{l}$ and the sample 1 has the highest value $1432 \mathrm{mg} / \mathrm{l}$. The analysis of influent samples shown in Table 1.

Table 1:-Analysis of influent samples

\begin{tabular}{|c|c|c|c|c|c|c|}
\hline Parameter & Sample-1 & Sample-2 & Sample-3 & Sample-4 & Sample-5 & Sample-6 \\
\hline $\mathrm{pH}$ & 6.95 & 6.89 & 6.98 & 7.1 & 6.92 & 6.99 \\
\hline $\begin{array}{l}\text { Conductivity } \\
\mathrm{mS} / \mathrm{cm}\end{array}$ & 8.4 & 7.18 & 7.12 & 6.44 & 6.88 & 7.10 \\
\hline BOD mg/l & 337 & 340 & 270 & 290 & 250 & 310 \\
\hline COD mg/l & 484 & 490 & 560 & 710 & 650 & 490 \\
\hline S.S mg/l & 498 & 289 & 129 & 309 & 204 & 180 \\
\hline T.D.S mg/l & 934 & 998 & 910 & 920 & 924 & 926 \\
\hline T.S mg/l & 1432 & 1287 & 1039 & 1192 & 1064 & 1092 \\
\hline
\end{tabular}




\section{The effluent samples analysis:-}

The effluent samples $\mathrm{pH}$ values varied from 7.42 to 7.51 .The sample 1 has the lowest $\mathrm{pH} 7.42$ and the sample 4 has the highest $\mathrm{pH}$ 7.51.The conductivity values varied from $1.5 \mathrm{mS} / \mathrm{cm}$ to $1.8 \mathrm{mS} / \mathrm{cm}$. The sample 4 has the lowest value $1.5 \mathrm{mS} / \mathrm{cm}$ and the sample 1 has the highest value $1.8 \mathrm{mS} / \mathrm{cm}$. The BOD values varied from $4 \mathrm{mg} / \mathrm{l}$ to $10 \mathrm{mg} / \mathrm{l}$. The sample 5 has the lowest BOD value $4 \mathrm{mg} / \mathrm{l}$ and the sample 1 has the highest BOD value $10 \mathrm{mg} / \mathrm{l}$. The COD values varied from $18 \mathrm{mg} / \mathrm{l}$ to $20 \mathrm{mg} / \mathrm{l}$. The samples 2 and 4 have the lowest COD value $18 \mathrm{mg} / \mathrm{l}$ and the samples 3 and 5 have the highest value $20 \mathrm{mg} / \mathrm{l}$. The suspended solids varied from $6 \mathrm{mg} / \mathrm{l}$ to $9 \mathrm{mg} / \mathrm{l}$. The samples 4 and 6 have the lowest value $6 \mathrm{mg} / \mathrm{l}$ and sample 3 has the highest value $9 \mathrm{mg} / \mathrm{l}$. The total dissolved solids values varied from 860 $\mathrm{mg} / \mathrm{l}$ to $912 \mathrm{mg} / \mathrm{l}$. the sample 5 has the lowest value $860 \mathrm{mg} / \mathrm{l}$ and the sample 6 has the highest value $912 \mathrm{mg} / \mathrm{l}$. The total solids varied from $891 \mathrm{mg} / \mathrm{l}$ to $944 \mathrm{mg} / \mathrm{l}$. The sample 3 has the lowest value $891 \mathrm{mg} / \mathrm{l}$ and the samples 5 and sample 6 have the highest value $944 \mathrm{mg} / \mathrm{l}$. The analysis of effluent samples shown in Table 2.

Table 2:-Analysis of effluent samples

\begin{tabular}{|c|c|c|c|c|c|c|}
\hline Parameter & Sample-1 & Sample-2 & Sample-3 & Sample-4 & Sample-5 & Sample-6 \\
\hline $\mathrm{pH}$ & 7.42 & 7.44 & 7.45 & 7.51 & 7.49 & 7.43 \\
\hline $\begin{array}{c}\text { Conductivity } \\
\mathrm{mS} / \mathrm{cm}\end{array}$ & 1.8 & 1.6 & 1.6 & 1.5 & 1.6 & 1.7 \\
\hline BOD mg/l & 10 & 4 & 6 & 6 & 4 & 6 \\
\hline COD mg/l & 19 & 18 & 20 & 18 & 20 & 19 \\
\hline S.S mg/l & 8 & 7 & 9 & 6 & 8 & 6 \\
\hline T.D.S mg/l & 900 & 890 & 870 & 882 & 860 & 912 \\
\hline T.S mg/l & 920 & 919 & 891 & 938 & 944 & 944 \\
\hline
\end{tabular}

The Treatment Efficiency: Treatment Efficiency calculation:

Treatment efficiency $\%=\mathrm{C}_{\mathrm{i}}-\mathrm{C}_{\mathrm{e}} / \mathrm{C}_{\mathrm{i}} \times 100$

Where $\mathrm{Ci}=$ Parameter influent concentration $\mathrm{mg} / \mathrm{l}$

$\mathrm{C}_{\mathrm{e}}=$ Parameter effluent concentration $\mathrm{mg} / \mathrm{l}$

The BOD reduction efficiency varied from $97 \%$ to $98.8 \%$. The sample 1 has the lowest value $97 \%$ and the sample 2 has the highest value $98.8 \%$. The COD reduction efficiency varied from $96 \%$ to $97.4 \%$. The sample 1 has the lowest value $96 \%$ and the sample 4 has the highest value $97.4 \%$. The Nizwa new STP BOD and COD removal efficiency was $97 \%$ and $94 \%$ respectively.( Satyanarayana 2015). The treatment efficiency values were shown in Table 3 and Fig 1.

Table 3:-Treatment Efficiency

\begin{tabular}{|c|c|c|c|c|c|c|}
\hline Parameter & Sample-1 & Sample-2 & Sample-3 & Sample-4 & Sample-5 & Sample-6 \\
\hline BOD -\% & 97 & 98.8 & 97.7 & 97.9 & 98.4 & 98 \\
\hline COD - \% & 96 & 96.3 & 96.4 & 97.4 & 96.9 & 96.1 \\
\hline
\end{tabular}

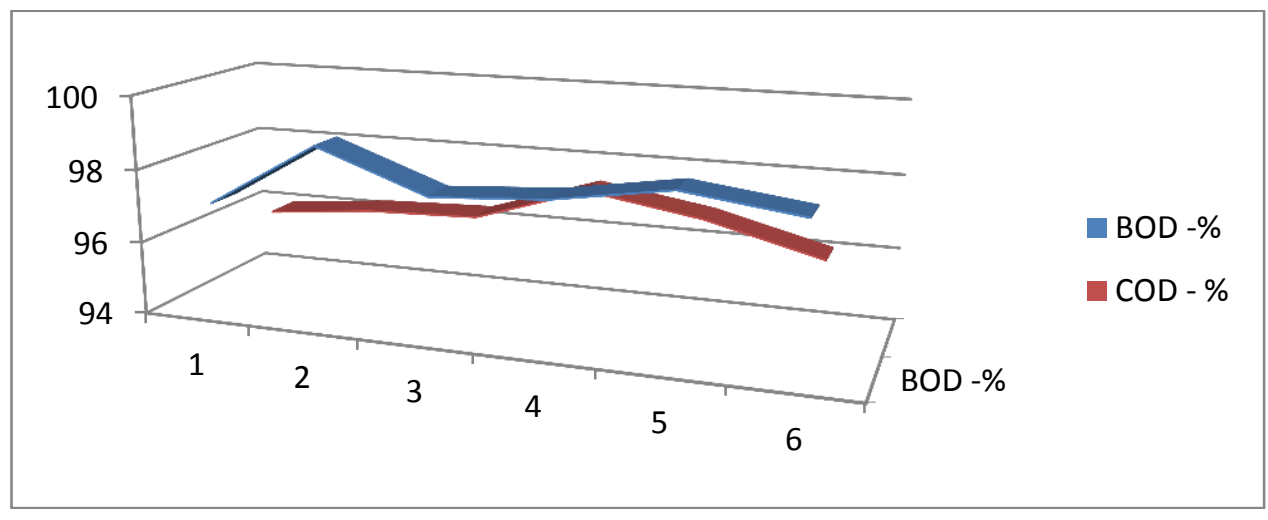

Fig1:-Treatment efficiency values. 


\section{Conclusions:-}

The average BOD reduction efficiency was $97.97 \%$ and the COD reduction efficiency was $96.51 \%$. The $\mathrm{pH}, \mathrm{BOD}$, COD and Suspended solids were within the prescribed standards. The conductivity and total dissolved solids values were below the prescribed water standards for agriculture use. The treated effluent can be used for agriculture purpose.

\section{References:-}

1. Ahansazan.B, Afrashteh.H, Ahansazan.N, and Ahansazan.Z. 2014." Activated Sludge Process Overview". International Journal of Environmental Science and Development, 5, (1),pp.81-85.

2. Andrade.L.H, Motta.G.E, Amaral .M.C.S. (2013)."Treatment of dairy wastewater with a membrane bioreactor" Brazilian Journal of Chemical Engineering.. 30(4) pp. 759-770.

3. Ester Coppini, Laura Palli,* ID, Donatella Fibbi and Riccardo Gori .2018. "Long-Term Performance of a FullScale Membrane Plant for Landfill Leachate Pretreatment: A Case Study".Membranes (MDPI). 8(52),pp.1-10.

4. Jayashree Dhote, Sangita Ingole, Aravind Chavhan.(2012).Review on Wastewater Treatment Technologies. International Journal of Engineering Research \& Technology.1 (5), pp. 1-10.

5. Metcalf \& Eddy. Wastewater Engineering Treatment and Reuse. McGraw Hill Education, Fourth Edition, 2003,New Delhi.

6. Naghizadeh .A,. Mahvi (B) A. H. Mesdaghinia. A. R. Alimohammadi. M. (2011). Application of MBR Technology in Municipal Wastewater Treatment.36.pp.3-10.

7. Oliver Terna Iorhemen *, Rania Ahmed Hamza and Joo Hwa Tay.2016. Membrane Bioreactor (MBR) Technology for Wastewater Treatment and Reclamation: Membrane Fouling. Journal of Membranes (MDPI). 6 (33), pp. 1-29.

8. Pal.P.Khairnar.K.Paunikar. W.N.2014. Causes and Remedies for Filamentous Foaming in Activated Sludge Treatment Plant. Global NEST. 16,( 4), pp. 762-772,

9. Satyanarayana SV, Natiq Joodi, Ali Saleh Al Kendy.2015. Treatment efficiency study of Nizwa new sewage treatment plant. International Journal of Applied Research. 1(8), pp. 635-637. 